\title{
Analisa Penggunaan Bahan Bakar Bioetanol Dari Limbah Kertas Sebagai Bahan Bakar Genset
}

\author{
Yoppy Hartantio ${ }^{1}$, Rukmi Sari Hartati ${ }^{2}$, I Nyoman Satya Kumara ${ }^{3}$
}

\begin{abstract}
The high fuel demand in Indonesia has resulted in an increase in the ratio of imported fuels and weakened domestic energy security. In response to this, biofuels (BBN) was developed, one of which was bioethanol. The raw material for making bioethanol can be from a variety of objects, but paper is the most easily obtained bioethanol raw material around us. PT Temprina Media Grafika a subsidiary of Jawa Pos Group produces waste paper every day. From the waste is processed into bioethanol and is used as a generator fuel. From $1 \mathrm{~kg}$ of paper waste obtained $30 \mathrm{ml}$ of bioethanol with a concentration of $86 \%$. By mixing bioethanol in gasoline, a mixture of fuels called E85, E60 and E35 is obtained. While pure RON 88 gasoline from Pertamina is called E10. Through testing on the generator set with a load of 600 watts and 900 watts, measurements of voltage, power, frequency, RPM and SOFC were obtained that all parameters decreased when using bioethanol mixed fuels.
\end{abstract}

Kata Kunci- Bioethanol, Biofuels, Waste Paper, Generator, Renewable Energy.

Intisari- Kebutuhan BBM di indonesia yang tinggi mengakibatkan rasio impor BBM meningkat dan menyebabkan ketahanan energi dalam negeri melemah. Menyikapi hal tersebut dikembangkanlah bahan bakar nabati (BBN) salah satu diantaranya yaitu bioetanol. Bahan baku pembuatan bioetanol bisa dari berbagai macam benda, namun kertas merupakan bahan baku bioetanol yang paling mudah didapat disekitar kita. PT Temprina Media Grafika anak perusahaan dari Jawa Pos Group menghasilkan limbah kertas tiap harinya. Dari limbah tersebut diolah menjadi bioetanol dan dimanfaatkan sebagai bahan bakar genset. Dari $1 \mathrm{~kg}$ limbah kertas didapat $30 \mathrm{ml}$ bioetanol dengan konsentrasi $86 \%$. Dengan mencampurkan bioetanol pada bensin diperoleh bahan bakar campuran yang disebut E85, E60, dan E35. Sedangkan bensin murni RON 88 dari pertamina disebut E10. Melalui pengujian pada genset dengan beban 600 watt dan 900 watt kemudian dilakukan pengukuran voltase, daya, frekuensi, RPM dan SOFC diperoleh bahwa semua parameter mengalami penurunan saat menggunakan bahan bakar campuran bioetanol.

Kata Kunci- Bioetanol, Bahan Bakar Nabati, Limbah Kertas, Genset, Energi Terbarukan

\section{PENDAHULUAN}

\footnotetext{
${ }^{\top}$ Mahasiswa, Pascasarjana Magister Teknik Elektro Universitas Udayana, Jln. Cokroaminoto Gang Katalia No. 26 Ubung Denpasar Hp: 085646149142; e-mail: yoppyhartantio@gmail.com

Dosen Jurusan Teknik Elektro Fakultas Teknik Universitas Udayana, Jln. Jalan Kampus Bukit Jimbaran 80361 INDONESIA telp: 0361-703315; fax: 0361-703315email: ${ }^{2}$ rshartati@gmail.com, ${ }^{3}$ satya.kumara@unud.ac.id
}

Peningkatan konsumsi Bahan Bakar Minyak (BBM) di dalam negeri dan penurunan produksi minyak bumi telah menyebabkan ekspor minyak bumi menurun, sebaliknya impor minyak bumi dan BBM terus meningkat. Kondisi tersebut terlihat dari kenaikan rasio ketergantungan impor BBM dimana rata-rata meningkat dari $35 \%$ pada 2007 dan menjadi 44\% di tahun 2015 [1]. Hal ini menyebabkan ketahanan energi dalam negeri melemah.

Untuk menyikapi hal tersebut dikembangkanlah BBN (bahan Bakar Nabati). Diantara BBN tersebut terdapat bioetanol yang saat ini produksinya didunia semakin meningkat. Bioetanol sendiri merupakan bahan bakar dari tumbuhan yang memiliki sifat menyerupai minyak premium [2]. Bioetanol adalah etanol yang dihasilkan dari fermentasi glukosa (gula) yang dilanjutkan dengan proses distilasi. Bahan baku pembuatan bioetanol dibagi menjadi 3 kelompok: bahan sukrosa contohnya yaitu nira dan tebu, bahan pati contohnya jagung dan singkong, dan bahan selulosa contohnya kayu dan kertas [3]. Ditinjau dari ketersediaan bahan bakunya, maka kertas adalah bahan baku bioetanol yang paling mudah didapat disekitar kita. Disamping itu karena kandungan selulosa dalam kertas HVS sekitar 90\% dari berat kertas tersebut menjadikan kertas sebagai bahan baku bioetanol yang berpotensi tinggi. [4]

PT Temprina Media Grafika anak perusahaan dari Jawa Pos Group yang merupakan perusahaan dalam bidang percetakan dalam proses produksinya menghasilkan limbah kertas tiap hari, limbah tersebut bermacam-macam jenis namun ada satu limbah yang sangat memberikan dampak yang buruk bagi kesehatan para karyawan yaitu limbah serutan kertas karena bentuknya yang berupa cacahan kertas menghasilkan debu yang mengotori dan mengganggu pernafasan. Karena dampaknya akan lingkungan yang begitu besar maka diperlukan terobosan agar limbah ini cepat dapat diolah atau dimanfaatkan. Karena kandungan selulosa didalamnya maka limbah tersebut dapat dimanfaatkan sebagai bahan baku bioetanol. Dengan bentuk limbah kertas yang berupa cacahan dan berukuran kecil akan memudahkan untuk dijadikan bioetanol.

Bioetanol untuk bahan bakar bisa diterapkan pada mesin otto penemuan dari Nikolaus Otto yang merupakan sebuah tipe mesin pembakaran dalam yang menggunakan nyala busi untuk proses pembakarannya [5]. Di PT. Temprina Media Grafika cabang bali mempunyai dua buah genset yang satu genset diesel dan yang satunya bermesin otto dimana digunakan ketika terjadi pemadaman listrik agar kantor tetap beroperasi. Berdasarkan pemaparan tersebut maka diadakan studi mengenai pemanfaatan limbah kertas tersebut sebagai bioetanol untuk bahan bakar genset di PT. Temprina Media Grafika. 


\section{BIOETANOL}

Bioetanol berasal dari dua kata yaitu "bio" dan "etanol" dari dua kata tersebut maka dapat diartikan bahwa bioetanol adalah etanol yang berasal dari sumber hayati. Secara garis besar penggunaan bioetanol adalah sebagai pelarut untuk zat organik maupun anorganik, bahan dasar industri asam cuka, ester, spirtus, asetal dehid, antiseptik dan sebagai bahan baku pembuatan eter dan etil ester, untuk campuran minuman dan dapat digunakan sebagai bahan bakar (gasohol) [6].

Karena bioetanol dapat dijadikan bahan bakar, maka bioetanol merupakan salah satu biofuel yang hadir sebagai bahan bakar alternatif yang lebih ramah lingkungan dan sifatnya yang terbarukan. Selain dari tumbuhan bioetanol juga dapat dibuat dari kayu atau limbah kertas karena kandungan selulosa didalamnya [7].

Ditinjau dari ketersediaan bahan bakunya, maka kertas adalah bahan baku bioetanol yang paling mudah didapat disekitar kita. Pengolahan bioetanol dari bahan kertas secara ringkas dijelaskan oleh Meceiras (2016) melalui flowchart dalam jurnalnya sebagai berikut :

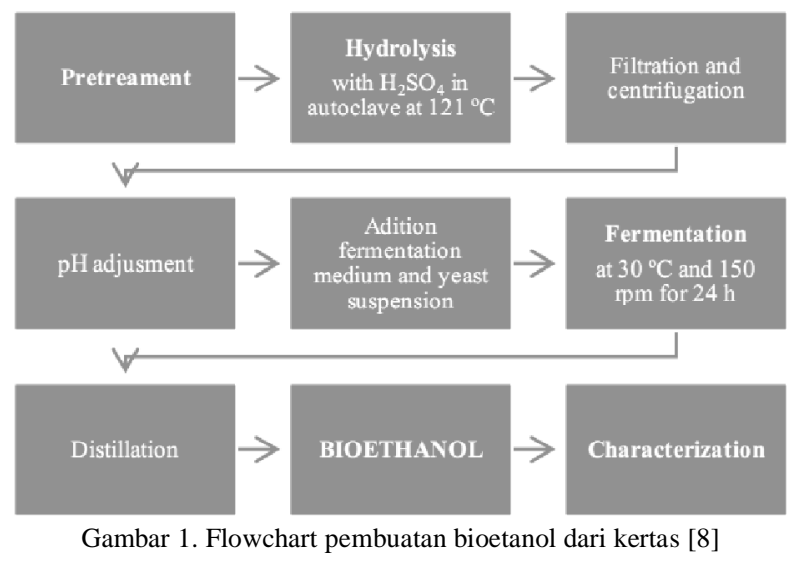

PT. Temprina Media Grafika (jawa pos group) sebagai salah satu perusahaan percetakan terbesar menghasilkan berbagai macam limbah kertas dalam proses produksinya. Limbah kertas yang dihasilkan perhari bisa mencapai puluhan atau ratusan kilogram, tergantung dari berapa banyak produksi yang dilakukan. Limbah kertas biasanya hanya dijual ke pengepul untuk perusahaan packaging, dijual lagi dalam bentuk yang lebih kecil atau di daur ulang. Namun pada jenis limbah serutan kertas tidak terdapat nilai ekonomis di dalamnya karena susah untuk dijual dan selama ini hanya dibuang saja ke tempat sampah. Namun karena volumenya yang banyak dimana perhari bisa dihasilkan sekitar 98,5 Kg dan dapat mengganggu pernafasan maka dari itu dibutuhkan terobosan baru untuk mengelola limbah kertas tersebut agar nilai ekonomisnya bertambah.

Karena limbah kertas mengandung selulosa maka limbah tersebut bisa dijadikan bahan dasar pembuatan bioetanol. Makin tinggi kandungan selulosa pada kertas maka jumlah glukosa yang dihasilkan pada proses hidrolisis enzimatis akan lebih besar [4]. Sehingga dalam hal ini pemanfaatan limbah kertas PT. Temprina Media Grafika dapat dianjurkan untuk dilakukan. Dengan memanfaatkan limbah kertas diharapkan nantinya dampak akan limbah kertas dalam perusahaan tersebut dapat berkurang terutama dalam hal kesehatan dimana pada limbah serutan kertas, debu kertas akan mencemari udara dan mengganggu pernafasan para pekerja didalamnya.

Pengolahan bioetanol dari limbah kertas memiliki sedikit perbedaan dengan bahan yang lainnya. Karena dalam proses pengolahannya, kertas memiliki kandungan lignin yang harus dihilangkan terlebih dahulu. Secara jelas prosesnya antara lain adalah sebagai berikut :

- Pretreatment (delignifikasi) : Untuk menghilangkan kandungan lignin dilakukan proses delignifikasi yang menggunakan proses kimiawi dengan menggunakan senyawa $\mathrm{NaOH}$ sebagai katalis

- Hidrolisis : proses untuk mengkonversi selulosa menjadi glukosa dalam penelitian ini proses hidrolisis dilakukan secara biologi dengan menambahkan cairan $\mathrm{Em}_{4}$

- Fermentasi : Proses fermentasi ini akan merubah glukosa dari limbah kertas tersebut menjadi etanol dengan menggunakan ragi

- Destilasi : suatu metode pemisahan bahan kimia berdasarkan perbedaan kecepatan atau kemudahan menguap. Karena dalam hasil fermentasi masih terdapat air yang dapat mengganggu kadar etanol yang diperoleh maka dilakukan destilasi untuk memisahkan air dan etanol tersebut.

Jika setelah dilakukan destilasi dan diukur kandungannya menggunakan alkoholmeter, kandungan etanol masih belum mencapai batasan minimal untuk grade bahan bakar maka dilakukan proses destilasi lagi sampai mencapai kandungan prosentase etanol yang diinginkan dan kemudian akan diukur volume etanol yang didapatkan.

\section{METODE PENELITIAN}

Dalam penelitian ini menggunakan metode eksperimen dan dokumentasi. Dengan mencatat dan mengamati perubahan parameter yang terjadi, sehingga nantinya akan diperoleh data-data dan akan dibandingkan dengan hasil akhirnya.

\section{A. Pembuatan bioetanol dari limbah kertas}

Dimulai dengan penimbangan limbah serutan kertas seberat $1 \mathrm{Kg}$ dan kemudian dilakukan proses delignifikasi yaitu proses untuk menghilangkan kandungan lignin dilakukan menggunakan proses kimiawi dengan menggunakan senyawa $\mathrm{NaOH}$ sebagai katalis. Limbah serutan kertas tersebut di campur dengan larutan $\mathrm{NaOH}$ $15 \%$ dengan perbandingan $1: 2,5$ kemudian didiamkan selama 1 jam untuk memaksimalkan proses.

Langkah selanjutnya adalah hidrolisis yang merupakan proses untuk mengkonversi selulosa menjadi glukosa dimulai dengan menyiapkan autoclave dengan suhu $121^{\circ} \mathrm{C}$ kemudian memasukkan limbah serutan kertas bersama cairan $\mathrm{NaOH}$ tadi dan dipanaskan selama 30 menit. Setelah itu ditiriskan dan limbah bubur kertas tersebut di cuci dengan air mengalir sampai PH normal kemudian karena dalam penelitian ini proses hidrolisis dilakukan secara biologi maka dilakukan penambahan cairan $\mathrm{Em}_{4}$ sebanyak $20 \mathrm{ml}$.

Kemudian dilakukan proses fermentasi yang akan merubah glukosa dari limbah kertas tersebut menjadi etanol dengan menggunakan ragi. Sebelum memulai 
limbah bubur kertas tersebut diatur PH nya agar asam dengan menambahkan $\mathrm{PH}$ buffer sampai $\mathrm{PH}$ nya 4,8 dan dimasukkan dalam toples kaca yang kedap udara untuk menghasilkan kondisi anaerob. Perbandingan ragi yang dipakai yaitu 1 : 0,006 dimana $1 \mathrm{Kg}$ Limbah serutan kertas membutuhkan 6 gr ragi. Proses fermentasi ini berlangsung selama 7 hari.

Setelah 7 hari kemudian dilakukan proses destilasi yaitu suatu metode pemisahan bahan kimia berdasarkan perbedaan kecepatan atau kemudahan menguap. Karena dalam hasil fermentasi masih terdapat air yang dapat mengganggu kadar etanol yang diperoleh maka dilakukan destilasi untuk memisahkan air dan etanol tersebut. Pada proses ini dengan proses destilasi sekali diperoleh bahwa $1 \mathrm{~kg}$ limbah serutan kertas menghasilkan $120 \mathrm{ml}$ bioetanol dengan kadar 14\% hal ini sangat jauh dari kadar yang ditetapkan untuk bioetanol bahan bakar maka dilakukan lagi destilasi secara bertingkat dan diperoleh 30 $\mathrm{ml}$ bioetanol dengan kadar $86 \%$

B. Data genset

Genset yang digunakan dalam penelitian ini adalah genset bermesin otto dengan spesifikasi sebagai berikut :

$\begin{array}{ll}\text { Merk } & : \text { Tekiro Ryu } \\ \text { Type } & : \text { RG } 1500 \\ \text { Fuel } & : \text { Bensin } \\ \text { Daya } & : 1.000 \text { watt (max) } \\ & 900 \text { watt (rated) } \\ \text { RPM } & : 3.600 \text { RPM } \\ \text { Phase } & : 1 \text { Phase }\end{array}$

Nantinya akan diuji dengan variasi bahan bakar bioetanol dan dengan pembebanan sesuai kapasitas rated dayanya dengan pembebanan 600 watt dan maksimal 900 watt.

C. Variasi bahan bakar bioetanol

Karena bioetanol 100\% memiliki panas laten yang tinggi hal ini akan mengakibatkan start pada mesin akan sangat susah karena pembakaran pada mesin memerlukan kondisi dimana bahan bakar harus menjadi uap, sedangkan bioetanol untuk menjadi uap memerlukan panas yang lebih tinggi dibandingkan bahan bakar minyak atau dalam hal ini bensin. Sehingga diperlukan pencampuran dengan bensin dalam penelitian ini.

Terdapat 4 campuran bahan bakar dalam penelitian ini yang dapat dilihat dalam tabel berikut :

TABEL 1.

VARIASI BAHAN BAKAR DALAM PENELITIAN

\begin{tabular}{|l|c|c|}
\hline \multicolumn{1}{|c|}{ Bahan bakar (v/v) } & $\begin{array}{c}\text { Kandunga } \\
\text { n alkohol }\end{array}$ & Disebut \\
\hline Bensin 100\% & $10 \%$ & E10 \\
\hline Bensin $85 \%$ bioetanol 25\% & $35 \%$ & E35 \\
\hline Bensin 50\% bioetanol 50\% & $60 \%$ & E60 \\
\hline Bensin 25\% bioetanol 75\% & $85 \%$ & E85 \\
\hline
\end{tabular}

Bensin disini menggunakan bensin dari pertamina dengan RON 88. Pada bensin pertamina RON 88 sudah terdapat kandungan alkohol didalamnya sebanyak 10\%. Karena melalui Keputusan Direktur Jenderal Minyak dan Gas Bumi nomor 3674.K/24/DJM/2006 tentang standar dan mutu (spesifikasi) bahan bakar minyak jenis bensin yang dipasarkan dalam negeri. Dijelaskan bahwa dalam SNI campuran bioetanol secara resmi disebut gasohol, dan secara umum penggunaan etanol pada semua jenis bensin (bensin jenis 88, 91 dan 95) diijinkan mencampur dengan etanol maksimal sebanyak $10 \%$.

D. Unjuk kerja genset

Unjuk kerja genset diperoleh dengan mengamati voltase, daya, frekuensi, RPM dan SFOC melalui pengujian genset dengan variasi bahan bakar E10, E35, E60 dan E85 kemudian genset diuji dan diamati dengan memberikan pembebanan 600 watt dan 900 watt. Hal yang diamati antara lain yaitu : Daya, Frekuensi, Tegangan, dan RPM diamati menggunakan multimeter, wattmeter dan tachometer.

Sedangkan untuk SFOC (Spesific Fuel Oil Consumption) menurut Kurniawan (2014) dalam jurnalnya, diperoleh dengan perhitungan menggunakan rumus sebagai berikut :

$S F O C=\frac{m f \times 10^{3}}{P_{B}}$

Dimana :

SFOC = konsumsi bahan bakar spesifik $(\mathrm{g} / \mathrm{kWh})$

$\mathrm{mf}=$ laju aliran bahan bakar $(\mathrm{kg} / \mathrm{jam})$

$\mathrm{PB}=$ Daya keluaran (kilowatt)

Untuk mf dihitung dengan rumus :

$$
m f=\frac{s g_{f} x V_{f}}{t_{f}} \times 3600
$$

Dimana :

sgf = Spesifik gravity ( $\mathrm{kg} /$ liter $)$

$\mathrm{Vf}=$ volume bahan bakar yang diuji (liter)

tf = waktu untuk konsumsi bahan bakar sejumlah Vf (detik)

E. Standar unjuk kerja genset

Untuk hasil dari pengukuran akan dibandingkan dengan standar dari Electrical Generating Systems Association (EGSA) ) dalam pedomannya pada "Engine Driven Generating Sets Performance Standard EGSA 101P, 1995a" diberikan standar akan parameter unjuk kerja genset antara lain yaitu :

- Voltase tidak boleh lebih atau kurang dari 5\% dari name plate.

- Frekuensi pada standar EGSA dalam klasifikasi ke 4, tidak boleh melebihi $7 \%$ dari name plate nya.

- Untuk speed (RPM) tidak boleh melebihi 25\% dan kurang dari $25 \%$ dari name plate nya.

- Untuk standar specific fuel consumption (SFOC) dari mesin genset berbahan bakar bensin adalah sebesar $250 \mathrm{~g} /(\mathrm{kW} . \mathrm{h})$.

p-ISSN:1693 - 2951; e-ISSN: 2503-2372 
TABEL 2.

STANDAR PARAMETER GENSET OLEH EGSA

\begin{tabular}{|c|c|c|c|c|c|}
\hline \multicolumn{2}{|c|}{ voltase (volt) } & \multicolumn{2}{c|}{ Frekuensi (Hz) } & \multicolumn{2}{c|}{ Speed (RPM) } \\
\hline $\begin{array}{c}\text { batas } \\
\text { bawah }\end{array}$ & $\begin{array}{c}\text { batas } \\
\text { atas }\end{array}$ & $\begin{array}{c}\text { batas } \\
\text { bawah }\end{array}$ & $\begin{array}{c}\text { batas } \\
\text { atas }\end{array}$ & $\begin{array}{c}\text { batas } \\
\text { bawah }\end{array}$ & $\begin{array}{c}\text { batas } \\
\text { atas }\end{array}$ \\
\hline 204,6 & 235,4 & 46,5 & 53,5 & 2700 & 4500 \\
\hline
\end{tabular}

\section{HASIL DAN PEMBAHASAN}

Dengan melakukan proses pembuatan bioetanol dari limbah kertas dengan langkah-langkah diatas dan dengan mengamati proses tersebut diperoleh :

\section{A. Hasil pembuatan bioetanol}

Dari $1 \mathrm{Kg}$ limbah serutan kertas diperoleh $30 \mathrm{ml}$ bioetanol dengan kadar $86 \%$ dengan proses destilasi bertingkat. Untuk mendapatkan 1 liter bioetanol diperlukan 33,3 Kg limbah serutan kertas.

B. Hasil unjuk kerja genset dengan variasi bahan bakar

Pada unjuk kerja diperoleh hasil dari variasi bahan bakar dan pembebanan antara lain yaitu :

TABEL 3.

HASIL PENGUJIAN GENSET DENGAN VARIASI BAHAN BAKAR

\begin{tabular}{|c|r|r|r|r|r|r|r|r|}
\hline & \multicolumn{2}{|c}{ E10 } & \multicolumn{2}{c|}{ E35 } & \multicolumn{2}{c|}{ E60 } & \multicolumn{2}{c|}{ E85 } \\
\hline Beban (watt) & \multicolumn{1}{|c|}{600} & \multicolumn{1}{|c|}{900} & 600 & \multicolumn{1}{|c|}{900} & 600 & 900 & 600 & 900 \\
\hline Daya (watt) & 611,4 & 996,3 & 512 & 995,4 & 512 & 995,2 & 512 & - \\
\hline RPM & 3288 & 3205 & 3130 & 2988 & 3055 & 2961 & 2947 & - \\
\hline Voltase (volt) & 228,7 & 228,7 & 229 & 229 & 228,9 & 228,9 & 229 & - \\
\hline Frekuensi (Hz) & 55,6 & 54,32 & 54,73 & 54,25 & 54,06 & 53,08 & 50,99 & - \\
\hline
\end{tabular}

Pada E85 dengan pembebanan 900 watt atau pada beban maksimal genset tidak bisa beroperasi dan langsung mati. Hal ini dikarenakan nilai kalor pada E10 (bensin pertamina) berada diangka 33,7 MJ/L sedangkan pada E85 nilai kalornya sebesar 25,2 MJ/L. Dengan nilai tersebut genset tidak dapat dioperasikan dengan beban maksimalnya 900 watt karena perbedaan yang terlalu jauh akan nilai kalor diantara keduanya. Dan dengan kondisi seperti itu bahan bakar E85 hanya bisa dibebani sampai pada beban 600 watt $(60 \%)$ dari total pembebanan maksimal genset tersebut.

\section{- Daya}

Untuk daya hasil yang diperoleh antara lain :

TABEL 4.

DAYA OUTPUT GENSET MENGGUNAKAN WATTMETER

\begin{tabular}{|c|r|r|r|r|}
\hline \multirow{2}{*}{ Daya } & \multicolumn{1}{|c|}{ E10 } & \multicolumn{1}{|c|}{ E35 } & \multicolumn{1}{|c|}{ E60 } & \multicolumn{1}{|c|}{ E85 } \\
\cline { 2 - 5 } & (watt) & (watt) & (watt) & (watt) \\
\hline 600 watt & 611,4 & 512 & 512 & 512 \\
\hline 900 watt & 996,3 & 995,4 & 995,2 & - \\
\hline
\end{tabular}

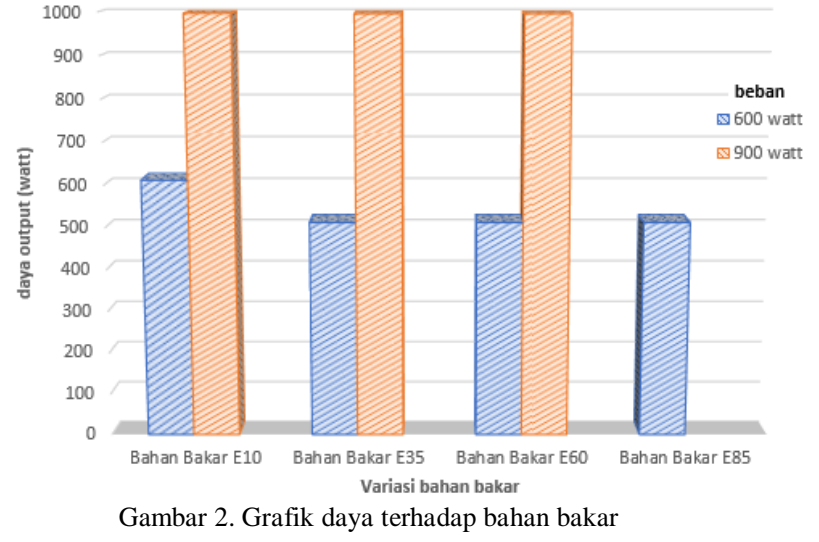

Dari grafik dan tabel diatas tidak ada perbedaan yang signifikan terhadap daya output yang dihasilkan genset saat diukur menggunakan wattmeter. Perbedaan yang terlihat hanya saat menggunakan bahan bakar E10 bensin RON 88 dari pertamina dimana saat dibebani 600 watt daya yang dihasilkan sebesar 611,4 watt lebih tinggi daripada saat menggunakan bahan bakar yang dicampur dengan bioetanol kertas.

\section{- Frekuensi}

Untuk frekuensi diperoleh hasil sebagai berikut :

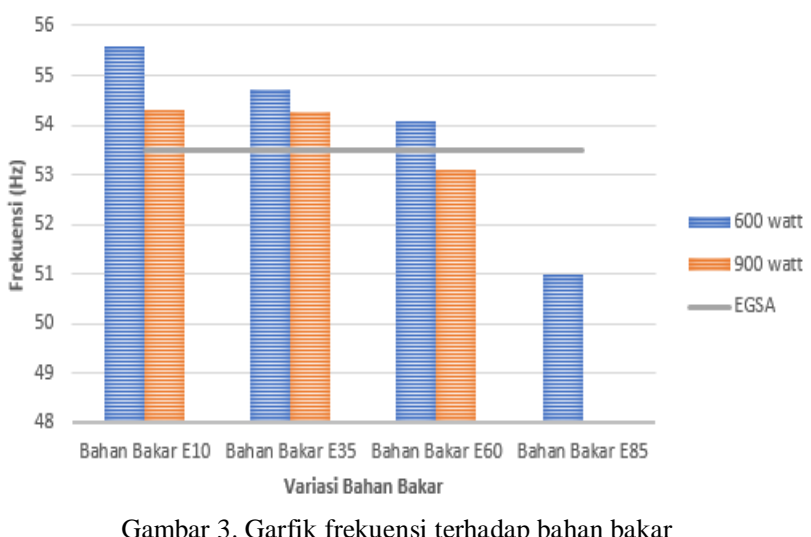

TABEL 5.

FREKUENSI GENSET DIUKUR MENGGUNAKAN MULTIMETER

\begin{tabular}{|c|c|c|c|c|}
\hline \multirow{2}{*}{ Frekuensi } & $\mathbf{E 1 0}$ & $\mathbf{E 3 5}$ & $\mathbf{E 6 0}$ & $\mathbf{E 8 5}$ \\
\cline { 2 - 5 } & $(\mathbf{H z})$ & $(\mathbf{H z})$ & $(\mathbf{H z})$ & $(\mathbf{H z})$ \\
\hline 600 watt & 55,6 & 54,73 & 54,06 & 50,99 \\
\hline 900 watt & 54,32 & 54,25 & 53,08 & - \\
\hline EGSA & 53,5 & 53,5 & 53,5 & 53,5 \\
\hline
\end{tabular}

Dari grafik dan tabel diatas dapat dilihat bahwa terjadi penurunan yang signifikan terhadap frekuensi jika kadar bioetanol dalam bahan bakar bertambah. Hal ini dikarenakan frekuensi berhubungan dengan putaran mesin dimana jika putaran mesin menurun otomatis frekuensi juga akan menurun. Dan jika dibandingkan dengan standar parameter EGSA, frekuensi diatas masih cenderung diatas batas standar yang telah ditetapkan EGSA yaitu melebihi $7 \%$ dari name plate genset tersebut. 
- Tegangan

Untuk tegangan pada genset setelah diukur menggunakan multimeter dan dengan penggunaan variasi beban diperoleh :

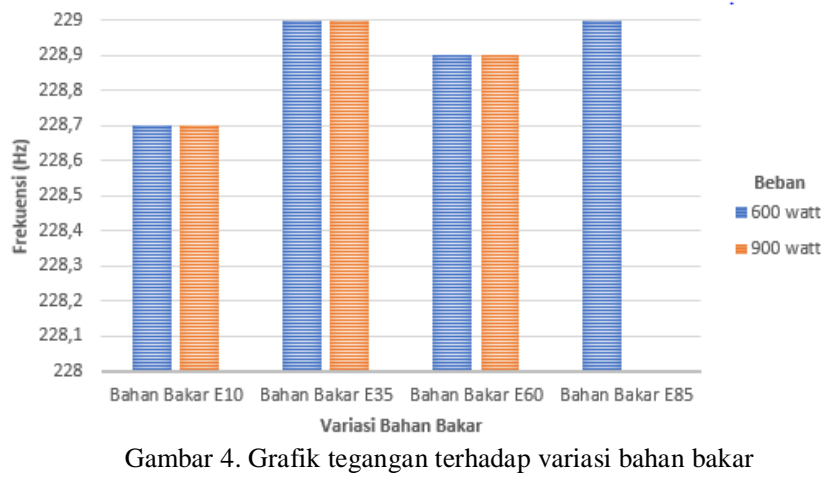

TABEL 6.

TEGANGAN GENSET DIUKUR DENGAN MULTIMETER

\begin{tabular}{|c|c|r|r|r|}
\hline \multirow{2}{*}{ Tegangan } & \multicolumn{1}{|c|}{ E10 } & \multicolumn{1}{c|}{ E35 } & \multicolumn{1}{c|}{ E60 } & E85 \\
\cline { 2 - 5 } & (Volt) & (Volt) & (Volt) & (Volt) \\
\hline 600 watt & 228,7 & 229 & 228,9 & 229 \\
\hline 900 watt & 228,7 & 229 & 228,9 & \\
\hline EGSA & 235,4 & 235,4 & 235,4 & 235,4 \\
\hline
\end{tabular}

Dari tabel dan grafik diatas tidak terdapat perbedaan yang berarti terhadap tegangan genset dengan pembebanan yang berbeda hanya terlihat saat menggunakan bahan bakar E10 bensin RON 88 pertamina, tegangan lebih rendah daripada saat menggunakan campuran bioetanol. Tegangan lebih stabil dikarenakan juga genset yang dipakai sudah menggunakan AVR (automatic voltage regulator) sehingga tegangan output genset sudah distabilkan oleh alat tersebut.

- $\quad$ SFOC (spesific fuel oil consumption)

Untuk segi penghematan bahan bakar dari data yang diperoleh dari pengamatan diatas akan dapat dihitung SFOC, dan dijelaskan dalam tabel berikut :

TABEL 7.

SFOC PADA GENSET DENGAN VARIASI BAHAN BAKAR

\begin{tabular}{|c|c|c|c|c|c|c|c|c|}
\hline & \multicolumn{2}{|c|}{ E10 } & \multicolumn{2}{|c|}{$E 35$} & \multicolumn{2}{|c|}{$\mathrm{E} 60$} & \multicolumn{2}{|c|}{585} \\
\hline $\begin{array}{l}\text { beban } \\
\text { (watt) }\end{array}$ & 600 & 900 & 600 & 900 & 600 & 900 & 600 & 900 \\
\hline Sgf & 0,72 & 0,72 & 0,74 & 0,74 & 0,75 & 0,75 & 0,76 & 0,76 \\
\hline $\mathrm{Vf}$ & 0,25 & 0,25 & 0,25 & 0,25 & 0,25 & 0,25 & 0,25 & - \\
\hline Tf & 530 & 270 & 560 & 280 & 600 & 320 & 650 & - \\
\hline$\overline{M f}$ & 0,12 & 0,24 & 0,12 & 0,24 & 0,11 & 0,21 & 0,11 & - \\
\hline $\mathrm{Pb}$ & 0,51 & 1,00 & 0,51 & 1,00 & 0,51 & 1,00 & 0,51 & - \\
\hline SFOC & $\begin{array}{r}238,8 \\
0\end{array}$ & $\begin{array}{r}240,8 \\
9\end{array}$ & $\begin{array}{r}232,2 \\
8\end{array}$ & $\begin{array}{r}238,9 \\
6\end{array}$ & $\begin{array}{r}219,7 \\
3\end{array}$ & $\begin{array}{r}211,9 \\
5\end{array}$ & $\begin{array}{r}205,5 \\
3\end{array}$ & \\
\hline
\end{tabular}

Keterangan :

$\mathrm{Sgf}=$ spesifik gravity $(\mathrm{kg} / \mathrm{liter})$,

$\mathrm{Vf}=$ volume bahan bakar yang digunakan (liter),

$\mathrm{tf}=$ waktu yang digunakan menghabiskan bahan bakar tersebut (detik), $\mathrm{mf}=$ laju aliran bahan bakar $(\mathrm{kg} / \mathrm{jam})$,

$\mathrm{pb}=$ daya keluaran (Kilowatt)

sfoc $=$ spesific fuel oil consumption $(\mathrm{g} / \mathrm{kWh})$

Yoppy Hartantio : Analisa Penggunaan Bahan Bakar ....
Dari grafik diatas Sgf (spesific grafity) diketahui akan meningkat dengan penambahan kadar bioetanol dalam bahan bakar. Dengan penambahan bioetanol maka akan semakin berat larutan bahan bakar tersebut karena alkohol sendiri masa jenisnya lebih tinggi daripada bensin. Dengan penambahan kadar bioetanol juga mempengaruhi pada tingkat waktu yang digunakan untuk menghabiskan bahan bakar tersebut dimana dalam arti kata lain yaitu lebih irit dan tahan lama dalam pemakainnya. Untuk SFOC (spesific fuel oil consumption) nya sendiri dapat dilihat secara jelas melalui grafik berikut :

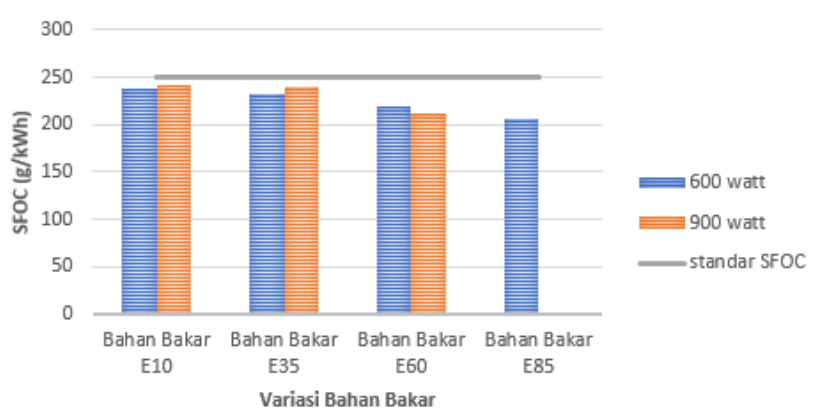

Gambar 5. Grafik SFOC terhadap variasi bahan bakar

TABEL 8. SFOC HASIL PERHITUNGAN

\begin{tabular}{|l|r|r|r|r|}
\hline \multirow{2}{*}{ SFOC } & \multicolumn{1}{|c|}{ E10 } & \multicolumn{1}{|c|}{ (35 } & \multicolumn{1}{|c|}{ E60 } & \multicolumn{1}{|c|}{ E85 } \\
\cline { 2 - 5 }$(\mathbf{g W h})$ & $(\mathbf{g} / \mathbf{k W h})$ & $(\mathbf{g} / \mathbf{k W h})$ & $(\mathbf{g} / \mathbf{k W h})$ \\
\hline 600 watt & 238,80 & 232,28 & 219,73 & 205,53 \\
\hline 900 watt & 240,89 & 238,96 & 211,95 & - \\
\hline standar SFOC & 250 & 250 & 250 & 250 \\
\hline
\end{tabular}

Dari hasil diatas dapat SFOC bahan bakar bioetanol mengalami penurunan dibandingkan bensin dari pertamina. SFOC menurun maka konsumsi bahan bakar menjadi irit dimana untuk mengeluarkan energi listrik per $\mathrm{kWh}$ nya semakin kecil. Konsumsi paling irit yaitu berada pada bahan bakar E85 yang nilai SFOC nya $205,5 \mathrm{~g} / \mathrm{kWh}$ dimana hanya membutuhkan 205,5 g bahan bakar untuk menghidupkan 1 $\mathrm{kWh}$

\section{KESIMPULAN}

Setelah dilakukan pembuatan bioetanol dari limbah kertas, pengambilan sampel serta pengujian terhadap genset, maka didapatkan kesimpulan sebagai berikut :

1) Dari $1 \mathrm{Kg}$ limbah kertas diperoleh bioetanol sebanyak $30 \mathrm{ml}$ dengan konsentrasi $86 \%$

2) Dari hasil uji performance mesin dengan variasi bahan bakar yaitu E85, E60, E35, dan E10 dapat disimpulkan bahwa daya, voltase, frekuensi, RPM, dan SFOC dari variasi konsentrasi bahan bakar bensin + ethanol (E85, E60, dan E35) lebih rendah dari pada dengan menggunakan bensin (E10). Dengan semua parameter yang lebih rendah dari bensin maka bahan bakar campuran bioetanol memiliki kualitas energi yang belum sebagus bensin namun sisi positif penggunaan bahan bakar campuran bioetanol tersebut adalah 
dengan SFOC yang rendah menyebabkan bahan bakar tersebut lebih irit dibanding bensin.

\section{REFERENSI}

[1] DEN. 2016. Outlook Energi Indonesia 2016. Jakarta : Sekertariat Dewan Energi Nasional

[2] Komarayati, Sri dan Gusmailina. 2010. Prospek Bioetanol Sebagai Pengganti Minyak Tanah. Bogor : Pusat Penelitian dan Pengembangan Hasil Hutan.

[3] Tajalli, Arief. 2015. Panduan Penilaian Potensi Biomassa Sebagai Sumber Energi Alternatif Di Indonesia. Penabulu Alliance.

[4] Fuadi, AM, Kun Harismah dan Adi Setiawan. 2015. "Hidrolisis Enzimatis Kertas Bekas Dengan Variasi Pemanasan Awal" University Research Colloquium. Vol. 1.

[5] Handayani, Sri Utami. 2007. "Pemanfaatan Bio Ethanol Sebagai Bahan Bakar Pengganti Bensin“ Gema Teknologi. Vol. 15 No.2.

[6] Wiratmaja, I Gede, I Gusti Bagus Wijaya Kusuma dan I Nyoman Suprapta Winaya. 2011. "Pembuatan Etanol Generasi Kedua Dengan Memanfaatkan Limbah Rumput Laut Eucheuma Cottonii Sebagai Bahan Baku" Jurnal Ilmiah Teknik Mesin Cakram Vol. 5 No.1. April 2011 (75-84)

[7] Kurniawan, Andre Dwiky, Semin dan Tjoek Suprajitno. 2014. “Analisa Penggunaan Bahan Bakar Bioethanol Dari Batang Padi Sebagai Campuran Pada Bensin” Jurnal Teknik Pomits. Vol. 3, No. 1.

[8] Maceiras, R, V. Alvonsin, dan J.E. Poole. 2016 "Bioethanol Production from Waste Office Paper” Journal Of Environmental Science.Vol 6 (7). 